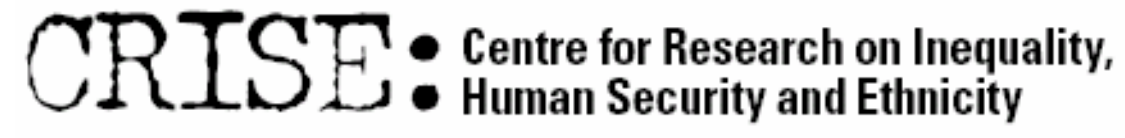

Department of International Development, University of Oxford

\title{
Policies towards Horizontal Inequalities
}

\author{
Frances Stewart, Graham Brown \\ and Arnim Langer
}

\section{CRISE WORKING PAPER No. 42 March 2007}

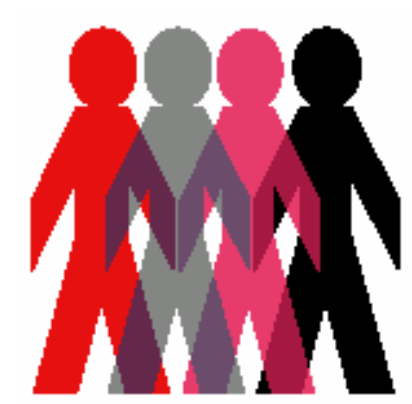




\title{
Policies towards horizontal inequalities
}

\begin{abstract}
Severe horizontal inequalities (HIs), or inequalities among groups, are undesirable in themselves and can lead to violent conflict. It is therefore important to reduce them, wherever possible. This paper reviews a range of policies which could contribute to reducing $\mathrm{HIs}$ in the political, socio-economic and cultural status dimensions. Relevant policies depend on the context and hence a first requirement is a careful assessment of the nature and causes of HIs in the particular society. Among many considerations to be taken into account, two are especially important. First, if possible, policies should be adopted which reduce rather than increase the salience of identities. Hence, the paper considers a range of indirect policies that are likely to reduce HIs because they are designed to help groups in which deprived groups are numerous, rather than direct policies targeted at the groups themselves. Secondly, policies which correct HIs can be provocative, leading to mobilisation (sometimes violent) by previously privileged groups, so that caution is needed in design and implementation. Examples of success in introducing such policies and sustaining peace - such as in Malaysia and Northern Ireland - show that policies can be effective without provoking a violent reaction. The successful socio-economic cases are shown to have tackled both social and economic inequalities, while success in reducing political HIs requires political inclusivity at many levels of the political system. The paper argues that considerations of $\mathrm{HI}$ are frequently ignored in policy-making, and need to become an important part of policy discussions in multicultural societies.
\end{abstract}

The authors

Arnim Langer is Research Officer in Economics and Politics, West Africa, at the Centre for Research on Inequality, Human Security and Ethnicity (CRISE), Department of International Development, University of Oxford.

Email: arnim.langer@qeh.ox.ac.uk

Graham Brown is CRISE Southeast Asia Research Officer.

Email: graham.brown@geh.ox.ac.uk

Frances Stewart is Professor of Development Economics at the University of Oxford and Director of CRISE.

Email: frances.stewart@geh.ox.ac.uk 


\section{Table of Contents}

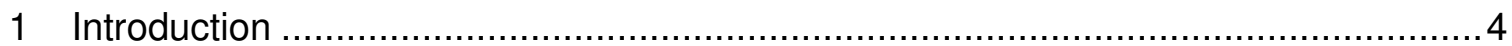

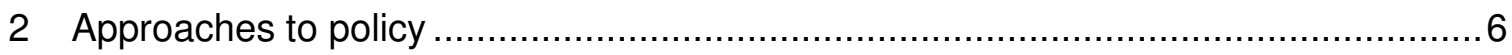

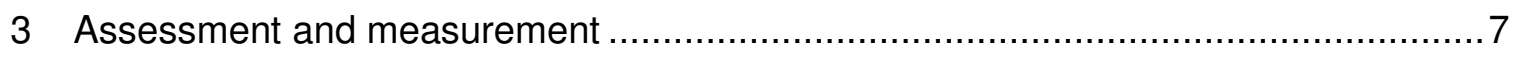

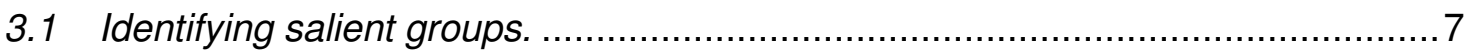

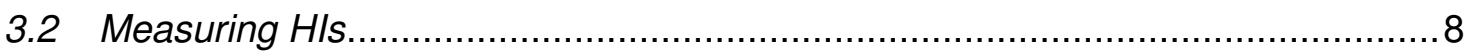

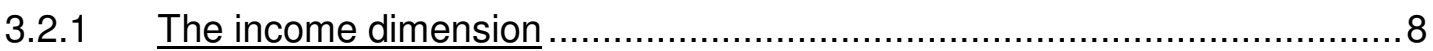

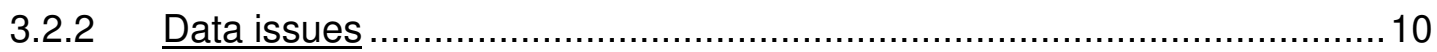

4 Policies towards political HIs ..................................................................... 11

4.1 The electoral system and political party regulations .....................................11

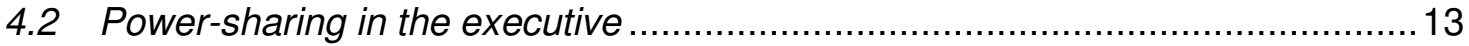

4.3 The composition of the bureaucracy and the security services.......................14

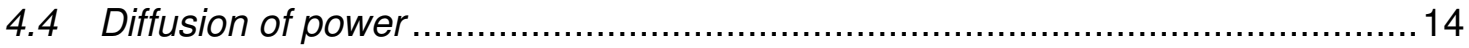

4.5 Conclusions on policies towards political HIs .......................................... 15

5 Policies towards socio-economic Hls: affirmative action ................................. 15

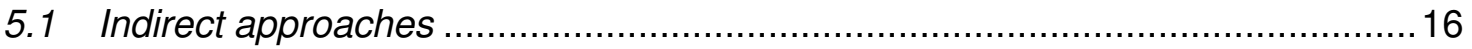

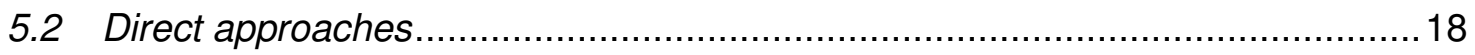

5.3 The need for economy-wide restructuring as well as fiscal and expenditure policies

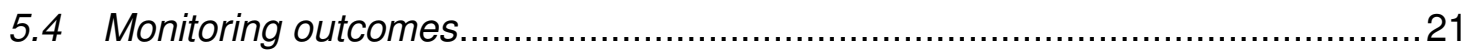

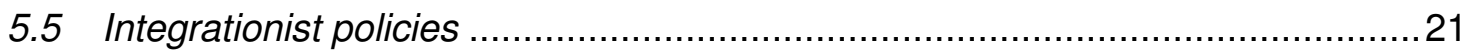

5.6 Conclusions on policies towards socio-economic Hls .................................23

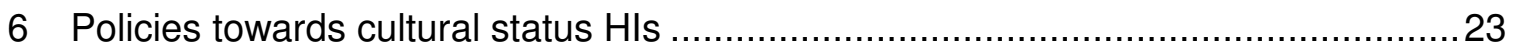

6.1 Religious practices and observances .................................................23

6.2 Language and language recognition ..................................................24

6.3 Policies towards ethno-cultural/religious practices ...................................26 
6.4 Conclusions on policies towards cultural status inequalities .........................27

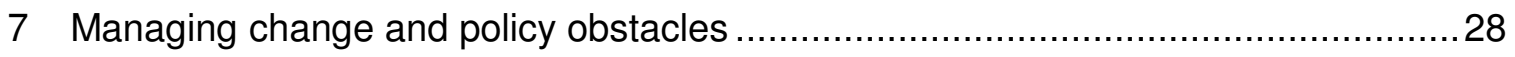

7.1 Initiating HI-management policies: getting support for the policies ..................28

7.2 Managing the implementation of HI policies: avoiding resistance .....................29

7.3 Managing the implementation of HI policies: the entrenchment of ethnicity......30

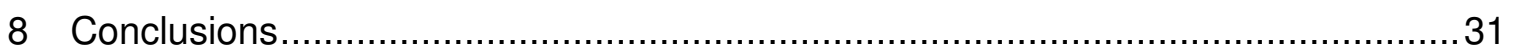

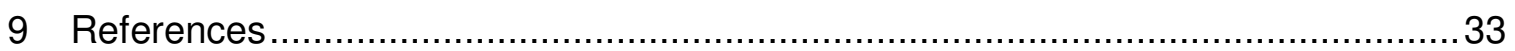

\section{List of Figures}

Figure 1: Schematic representation of conflict-inducing elements of HIs ......................5

\section{List of Tables}

Table 1: Examples of approaches to reducing Hls. ............................................... 7 


\section{Policies towards Horizontal Inequalities By Frances Stewart, Graham Brown and Arnim Langer}

\section{Introduction}

Horizontal inequalities (HIs) are inequalities among groups, with common felt cultural identities. These identities follow different lines across societies and across time. They include ethnic, religious, racial, or regional affiliations. Hls are multidimensional, including inequalities in access to political, economic and social resources, as well as in cultural recognition and status.

Research by the Centre for Research on Inequality, Human Security and Ethnicity (CRISE) suggests that large HIs, especially where consistent across dimensions and across salient group identities, generate conditions that increase the likelihood that a country may experience violent conflict. Moreover, severe Hls are also undesirable in themselves because they can create unhappiness among members of deprived groups, and may trap them in a situation of relative deprivation, which, for the group as a whole, can last generations. Therefore, where there are serious Hls in multicultural societies, it is important to include measures to ameliorate HIs in development policy. The need to do so is particularly pressing in countries that exhibit other conditions which appear to be conducive to conflict - low-income countries generally, and post-conflict countries in particular.

There are many considerations to be taken into account in designing development policies, particularly in a post-conflict environment, in addition to those directed at HIs. Thus, political policies usually aim to introduce democracy and the rule of law and to protect human rights generally; economic policies aim to achieve macro-economic stability, promote efficiency and growth and reduce poverty; and in post-conflict societies, policies also aim to reintegrate combatants, to reconstruct basic infrastructure and to address other important causes of conflict, such as unemployment and opportunities for rent-seeking. Policies towards Hls do not displace these other policy objectives or the relevant instruments to achieve them, but they may sometimes involve some trade-offs in policy objectives and some modifications in instruments. Moreover, the exact nature of policies is clearly context-specific and what is appropriate in one country may not be appropriate in another.

This paper reviews the range of policies which could contribute to alleviating the impact of HIs on conflict likelihood and its recurrence. The relationship between 'objective' horizontal inequalities and conflict is complex and mediated by at least two intervening factors - the perception of horizontal inequalities and the political salience of group identities. This relationship is depicted in a very stylised form in Figure 1. 


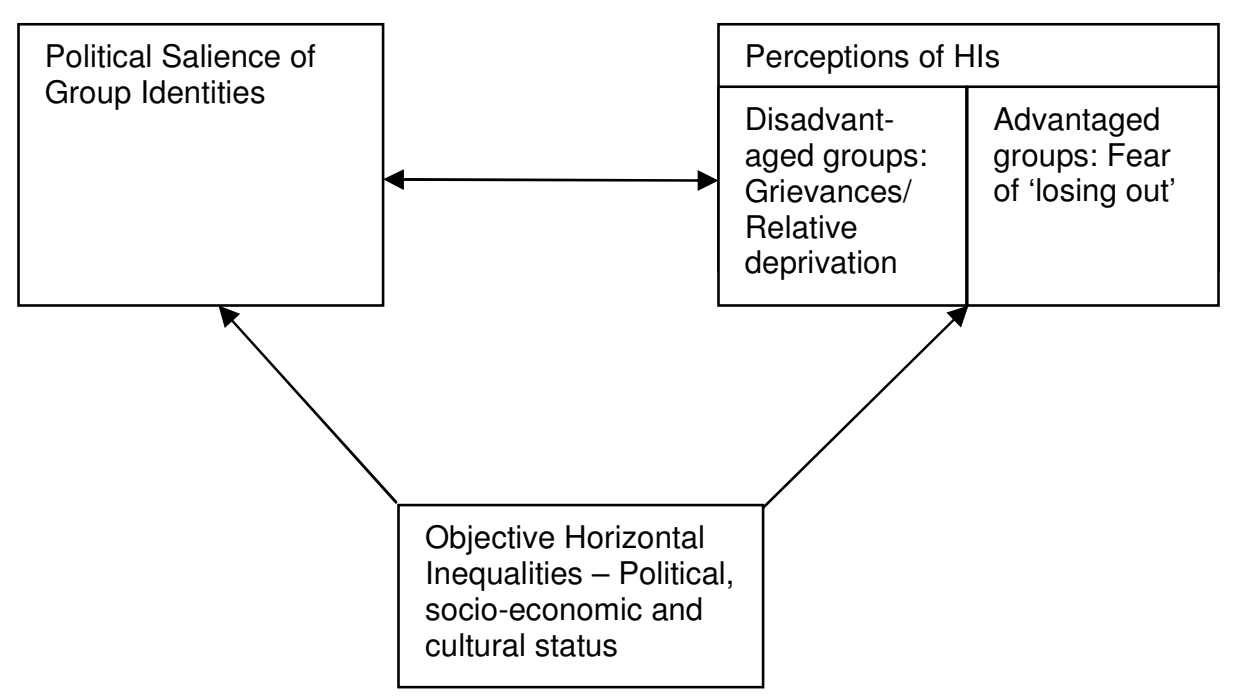

Figure 1: Schematic representation of conflict-inducing elements of Hls

Objective horizontal inequalities affect both perceptions of inequality and the political salience of group identities. The latter two factors are in turn closely linked. Dealing with perceptions of inequality is particularly complex from a policy perspective because different groups may have different views on what a just system would be, and on the origin of the observed inequalities. For relatively disadvantaged groups, particularly those experiencing persistent $\mathrm{HIs}$, HI-correction is likely to be seen as necessary to reverse historical injustices; for their relatively advantaged counterparts, however, HIs may be seen simply as a product of greater industry or a better work ethic on the part of the dominant group and, hence, HI-correction may be interpreted as unjust. Moreover, there may be a 'mismatch' between 'objective' and perceived HIs. In this paper we focus predominantly on policy options for reducing objective HIs. But securing accurate perceptions about inequalities is another important aspect of policy.

HIs are more likely to lead to conflict where cultural differences are believed to be marked. Moreover, the more entrenched cultural difference, the more difficult it can be for members of deprived groups to overcome their disadvantage because of prejudice and discrimination. Hence, reducing the sharpness and salience of group distinctions might also be an objective of policy - if achieved, it should reduce the propensity to mobilise along group lines, and may contribute to the reduction of Hls. We describe policies aimed at reducing group salience as 'integrationist'. ${ }^{1}$ In some cases, there are policies that contribute to reducing Hls without increasing salience (e.g. general antipoverty policies); but other policies (e.g. educational quotas for deprived groups) may achieve reduced Hls but at the expense of increased salience of group difference. In

${ }^{1}$ Our concept of 'integrationist' policies clearly corresponds closely to the broader literature on integrationism within the literature on managing ethnically divided countries, which emphasises policies that seek to encourage ethnic moderation and compromise and is most associated with the works of Donald Horowitz $(1985 ; 1989)$. Our concept however particularly relates to policies which seek to reduce the (political) salience of ethnic boundaries rather than encouraging crossgroup interaction. 
general, the first type of policies are to be preferred, given that they contribute to meeting both objectives - reduced HIs and greater integration. However, they may not be effective in reducing HIs, and in those circumstances we have to accept some tradeoffs in achieving the two objectives.

The paper is organised as follows. Section 2 introduces a typology of policy approaches drawn from the schematic model above. Sections 3 discusses measurement issues. Sections 4, 5 and 6 consider the range of policy options available in, respectively, the political, economic and cultural dimensions. Section 7 considers some obstacles to the proposed changes. Section 8 concludes with a discussion of some avenues for achieving policy change.

\section{Approaches to policy}

Drawing on case studies and the general findings of CRISE research, it is clear that different countries have taken different approaches to dealing with HIs. At one extreme, countries such as Malaysia have directly targeted horizontal inequalities through groupbased affirmative action policies. At the other extreme are a number of Latin American countries which have largely ignored horizontal inequalities altogether in their development programmes, despite the presence of persistent and serious HIs. Many countries fall somewhere in between, such as Ghana, which has pursued some policies aimed at correcting HIs, but has eschewed ethnic affirmative action in favour of regional policies aimed at providing additional development benefits to the historically disadvantaged northern regions. In this section, we introduce a typology of policy approaches and discuss the merits and demerits of each approach across the three dimensions of horizontal inequality - political, socio-economic and cultural status. Ultimately, the policies are aimed at eliminating, or substantially reducing, group inequality in economic well-being, political participation and cultural recognition. In practice, however, the policies have to be directed at processes affecting these outcomes, rather than at the outcomes themselves.

Policies across all three dimensions can take either a direct or indirect approach towards correcting group inequality. Direct approaches involve targeting groups directly, positively (for the deprived) and negatively (for the privileged). Indirect approaches aim to achieve the same $\mathrm{HI}$-reducing impact indirectly via general policies affecting everyone in society, but because of their design in relation to the circumstances of the various cultural groups in society, they reduce Hls. Ethnic quotas for education, or ethnic electoral rolls fall in the first category, while regional expenditure policies or decentralisation of power across the country fall in the second. As noted earlier, the first type of policy unavoidably increases the salience of identity difference, while the second is broadly neutral in this respect, and may indeed contribute to greater integration over time. Given the objective of reducing salience, it is desirable for the first type of policy to be time-limited. A third type of policy is explicitly directed at reducing the salience of group boundaries by increasing integration (and less concerned with $\mathrm{HI}$ reduction). Examples are incentives for shared economic or political activities across groups. 
Table 1: Examples of approaches to reducing Hls

\begin{tabular}{|c|c|c|c|c|}
\hline & \multicolumn{3}{|c|}{ Policy Approach } \\
\hline & & Direct HI-reducing & Indirect HI-reducing & Integrationist \\
\hline \multirow{3}{*}{$\begin{array}{l}\frac{c}{0} \\
\frac{0}{0} \\
\frac{E}{0}\end{array}$} & Political & $\begin{array}{l}\text { Group quotas; seat reservations; } \\
\text { consociational constitution; list } \\
\text { proportional representation }\end{array}$ & $\begin{array}{c}\text { Design of voting system to require } \\
\text { power-sharing across groups (e.g. } \\
\text { two-thirds voting requirements in } \\
\text { assembly); } \\
\text { design of boundaries and seat } \\
\text { numbers to ensure adequate } \\
\text { representation of all groups; } \\
\text { Human Rights legislation and } \\
\text { enforcement. }\end{array}$ & $\begin{array}{l}\text { Geographical voting spread } \\
\text { requirements; ban on } \\
\text { ethnic/religious political parties } \\
\text { (national party stipulations) }\end{array}$ \\
\hline & Socio-Economic & $\begin{array}{l}\text { Quotas for employment or } \\
\text { education; special investment or } \\
\text { credit programmes for particular } \\
\text { groups. }\end{array}$ & $\begin{array}{l}\text { Anti-discrimination legislation. } \\
\text { Progressive taxation. } \\
\text { Regional development programmes. } \\
\text { Sectoral support programmes (e.g. } \\
\text { Stabex) }\end{array}$ & $\begin{array}{l}\text { Incentives for cross-group } \\
\text { economic activities. } \\
\text { Requirement that schools are } \\
\text { multicultural. } \\
\text { Promotion of multicultural civic } \\
\text { institutions }\end{array}$ \\
\hline & Cultural Status & $\begin{array}{l}\text { Minority language recognition and } \\
\text { education; symbolic recognition } \\
\text { (e.g. public holidays, attendance at } \\
\text { state functions) }\end{array}$ & $\begin{array}{l}\text { Freedom of religious observance. } \\
\text { No state religion. }\end{array}$ & $\begin{array}{l}\text { Civic citizenship education; } \\
\text { promotion of an over-arching } \\
\text { national identity }\end{array}$ \\
\hline
\end{tabular}

Table 1 summarises some examples of HI-reducing and integrationist policies across the three main dimensions: political, socio-economic and cultural status. In subsequent sections, we will discuss these and other policy options in more detail. But first we briefly discuss the need for a careful country assessment, including measurement of HIs and identification of their major sources, before devising policy.

\section{Assessment and measurement}

\subsection{Identifying salient groups.}

The first step in understanding the status and dynamics of horizontal inequalities in a country is to classify the relevant identity groups: the group boundaries that people mind about, and the boundaries on the basis of which discrimination or favouritism occurs.

An initial in-depth investigation of the history and political economy of the country in question will suggest important group distinctions. Where surveys of people's own perceptions of identity distinctions are available, or such a survey can be carried out, this can provide valuable further insights. Such surveys ask people which groups they feel are privileged or deprived, and which are favoured or disfavoured by the government. They can also ask about the importance of different aspects of identity to the people themselves. Often it can be useful to adopt a multiple approach, examining a variety of group classifications (for example, ethnic, regional, and religious), and seeing where the main inequalities emerge.

Apart from defining the conflict-relevant groups, the scoping exercise should address four further questions: 
- Whether the salient groups are ranked hierarchically, that is, most members of one group are better off than the other group(s), or unranked, such that each group contains comparable fractions of rich and poor individuals (Horowitz 1985).

- Whether groups are geographically concentrated or dispersed.

- Whether groups are specialised on particular economic activities (e.g. one particular group mainly consists of traders, another of subsistence farmers, another of cash-crop farmers).

- Whether the government is politically inclined to tackle inequalities or instead wishes to preserve them. For shorthand, we can describe these two types as 'willing' or 'unwilling,' though in fact the situation may not be so clear cut. For example, the government's willingness may depend on the degree to which aid donors are prepared to support efforts to redress inequalities. And there may be divisions in the government on the issue.

Each of these questions is relevant for policy design.

\subsection{Measuring HIs}

\subsubsection{The income dimension}

While there is a voluminous literature on the measurement of vertical inequality, which has given rise to well-known measures such as the Gini coefficient, methods for measuring horizontal inequality have only begun to receive much attention (e.g. Stewart, et al. 2005). Here we review measurement issues for both income and non-income dimensions of $\mathrm{HI}$.

Providing summary information on horizontal inequality is more complex than summarising vertical inequality, precisely because we are now concerned with groups. This is most frequently represented by comparing the average per capita incomes of different groups, a measure that conceals distributional differences within groups. Yet from a political perspective, how groups compare at different points in the distribution may be relevant. In one case, for example, a group may outperform another uniformly at every income level; in a second case, a group's elite (say, the top 5\%) may have incomes far higher than the elite of the other group, but in the remaining $95 \%$ of the distribution the groups have the same income levels; in a third case, both groups may be equal at the top, but the bottom $40 \%$ of one group is far poorer than the bottom $40 \%$ of the other; and in a fourth case, one group may have higher income levels at the top of the distribution, but lower incomes at the bottom.

These differences have political and policy implications. From a political perspective, in the first case, both the elite and the masses of the lower-income group have grievances, a situation that may make rebellion more likely. Malaysia in the 1960s and apartheid South Africa are examples. In the second case, the elite has a grievance but not the rest of the population, perhaps making rebellion less likely.

In the third and fourth cases, the income disparities among the lower-income groups again may make rebellion less likely, unless the elite feel politically disenfranchised or threatened, in which case they may find it easy to mobilise support among the lower income groups. The Rwandan genocide in 1994 is an example. 
The differences are relevant from a policy perspective, too. In the first case, policies are needed both to increase entrepreneurial and civil-service opportunities at the top and to provide basic services and economic opportunities to the masses. In the second case, the focus of efforts to reduce tensions should be on elite opportunities. In the third and fourth cases, it is a matter of improving the position of poorer members of the group.

In addition to average per capita income, therefore, group distributional data should be analysed. Three useful ways of presenting such data are:

1. Comparing the proportions of each group in each income quantile relative to its proportion in the overall population. This enables one to see how far particular groups are over- or under-represented at different points in the income distribution.

2. Estimating the ratios of average incomes between two groups for each decile or quintile.

3. Estimating the general mean of the income distribution, using different weights. A general mean is a weighted mean; it can be weighted towards low values of incomes, in which case comparisons among groups would focus especially on how poorer members of the groups compare, or alternatively, the weighting can be chosen to emphasise differences among the upper income portions of the groups. The normal arithmetic mean is the special case where the weight given to each portion of the income distribution is equal ${ }^{2}$.

\subsubsection{Non-income dimensions}

Evidence on the multiple dimensions of HIs, not only on income, is needed. For planning public expenditure, policy makers need to know where the main problem lies. Is it, for instance, a matter of access to education, or poor economic opportunities, or both? Does access to land or employment show the sharpest inequalities, and which is most important to people? Data availability constraints are often severe, but certain areas that are fundamental to well-being should have priority for data collection. Apart from income, these include land and other assets; employment; educational access at various levels; and health outcomes such as infant and child mortality. Where the data permit, it is again desirable to compare performance in these non-income dimensions across the distribution, rather than relying simply on comparisons of average performance.

It is also possible to employ some of these measures to evaluate political horizontal inequalities through the analysis of the distribution between salient groups of positions within parliament, government and bureaucracy, etc. The key here is the concept of 'relative representation' (Langer 2005), defined as each group's share of the positions available divided by its share of the population. This relative representation can then be

${ }^{2}$ The formula is $\bar{X}_{\alpha}=\left(\sum_{i}^{n} X_{i}^{\alpha} / n\right)^{\frac{1}{\alpha}}$ See Foster, Lopez-Calva and Szekely (2003); Foster and Szekely (2006). 
used in the computation of a measure of political HIs. This clearly requires knowledge of the background of the relevant officials or politicians. In some cases this may be publicly available (e.g. in Nepal, see Brown and Stewart 2006). Where it is not, however, 'name recognition' techniques may be employable in some contexts to attribute group background (e.g. Langer 2005).

\subsubsection{Data issues}

Socio-economic data broken down by the relevant ethno-cultural categories are often scarce. Sometimes - as, for example, in Nigeria - ethno-cultural variables are not included in surveys because of their political sensitivity (Okolo 1999). For quick assessment, it may be necessary to use some other characteristic as a proxy for ethnocultural difference. Two such options are region and language.

Regional data are often more readily available. The degree to which they are useful for $\mathrm{HI}$ assessment depends on the extent to which identity groups are geographically segregated. As a rule of thumb, region is a useful proxy if more than half the members of the relatively deprived group are concentrated in the targeted region while less than half of the privileged group are in the targeted region. In many African countries, ethnic and religious groups are regionally concentrated so that regional inequality may be a suitable proxy. And in some cases, region itself defines group identities.

An alternative proxy is language, on which information is sometimes available when ethnic variables are not - as in Indonesian surveys in the New Order period. Comparison of Indonesian language statistics at the district level with ethnic data that became available at a later date shows close correlations, suggesting that language is an effective proxy for ethnicity in this context (Mancini 2005).

The first need in any country is to conduct an inventory of available data. Potential data sources include:

- Census data, which often include ethnicity or language, and sometimes religion.

- Demographic and Health Surveys (DHS), many of which include ethnic identification along with information on access to social services and ownership of domestic assets.

- Regional data from the census, household surveys and public expenditure accounts.

- Specific sectoral data (e.g., from schools and hospitals) which often contain ethnic and regional information.

Urgent data gaps can be filled by 'light' surveys and use of focus groups.

Knowledge about the nature of HIs and their major sources is an essential background for designing policies to reduce Hls. The next three sections discuss relevant policies on the basis of experience across the world. Design of policy in a particular context may be informed by such experience, but must ultimately rest on in-depth knowledge of the society in question. 


\section{Policies towards political HIs}

Ensuring that each major group participates in the political arena and has access to power is a critical requirement for sustained peace, since political exclusion is likely to alienate group leaders, and hence give more incentives for group mobilisation against the state or against groups that are perceived as controlling the state. Therefore, action is needed to ensure that each group participates in political decision-making processes and political power. This does not happen automatically in either democratic or nondemocratic systems. Both formal and informal mechanisms can play a role in ensuring such political participation (or indeed exclusion). Political power is located at many levels - the executive, the legislative and the judiciary; at the centre and in local government; in the army and the police. Group participation needs to be identified at each of these levels, and appropriate policies devised. Moreover, the appropriate constitutional solution must be country specific, depending on a country's history, geography, and demographic composition. As Reynolds argues, 'when designing an appropriate electoral system that addresses the needs of a minority, the case context determines all' (Reynolds 2006: 4). Nonetheless, it is possible to make some points that are generally relevant.

Major considerations in tackling political HIs include the definition of citizenship, the design of the electoral system and rules of political competition, the composition of the executive and the way decisions are taken, the extent and nature of decentralisation, and policies towards employment in the bureaucracy, the police and army. There are clearly many different perspectives on these issues within the existing literature. Here we discuss them with specific references to tackling political HIs and political representativity within the broad policy approaches identified above.

\subsection{The electoral system and political party regulations}

There is already a significant theoretical and empirical literature relating to the appropriateness of different forms of electoral arrangements for multicultural societies. The two main approaches in the existing literature - the consociationalist approach, associated primarily with the works of Arend Lijphart (1977; 2004); and the integrationist approach, associated with Donald Horowitz (1985) - broadly correspond, respectively, with the direct approach to reducing political HIs and more indirect approaches intended both to reduce political HIs and to reduce the salience of group divisions. Consociationalists typically promote the institutionalisation (whether formally or informally) of a 'grand coalition' of groups as the basis of political office - in effect, ensuring all major groups are represented in government, thus alleviating political HIs. In contrast, the integrationist approach is less concerned with achieving a 'balance of power' between major groups than with devising mechanisms to reduce the incentives for group mobilisation which might be associated with reduced political Hls, but might not. A major problem with the latter approach is that if it does not succeed in reducing group imbalances in power, the system may break down - as has occurred in a number of cases where it was tried (e.g. Lebanon and Sri Lanka).

Turning to more specific measures, one set of political HI-reducing policies consists of electoral mechanisms designed to ensure balanced group representation in parliament, government, and the executive. Lijphart has suggested that the simplest way of ensuring ethnic representativity is to create separate electoral rolls with seats allocated by group rather than by geographic boundary, as has been implemented in Cyprus (for Turkish and Greek Cypriots) and in New Zealand, where a separate Māori electoral roll 
is kept (Lijphart 1986). An alternative mechanism is to create a single electoral roll but to reserve certain seats for certain groups. In India, around 15 per cent of parliament seats are reserved for Scheduled Castes, but registered electors from all groups in the constituency vote for them.

The mechanisms discussed thus far are all direct, group-based mechanisms and, as such, ensure a minimum balance of political representation at the expense of possibly entrenching identity politics as the basis of electoral mobilisation. More indirect, nongroup-based electoral mechanisms are also available which may encourage group balance within parliament. Most forms of proportional representation (PR) are likely to achieve a greater degree of balance than first-past-the-post systems, under which minorities 'tend to be severely under-represented or excluded' (Lijphart 1986: 113). In general, it appears that PR is an effective system to ensure that all groups are represented broadly in proportion to their population size, so long as the system has low thresholds for the minimum votes needed to justify election. We should note, however, that there may be a 'fair' electoral system, but exclusion can occur in the determination of who is entitled to the vote.

Integrationist policies in the political sphere typically relate both to reforms of the electoral system and to restrictions on political parties intended to reduce the ethnicisation of political parties and of politics. Political parties act as a critical mediating mechanism through which voter preferences are mobilised and expressed. In multiethnic societies, there is a strong tendency for political parties to become 'ethnic' as this seems to be an effective way of mobilising votes (Horowitz 1985). More broad-based coalitional parties can be encouraged by the electoral system - again through systems of 'list' PR, or a single transferable vote in multi-member districts (adopted e.g. in Malta and Ireland). Without some such constraining influences, political parties can be highly divisive in multicultural societies, with elections sometimes leading to conflict (Snyder 2000; Stewart and O'Sullivan 1999). Restrictions on political parties themselves are another integrationist policy. Thus in both Ghana and Nigeria, political parities have to have representatives throughout the country, and given the geographic concentration of ethnic groups this promotes multiethnic parties.

Another policy of political-HI management that has a long history is the (de facto) oneparty state. In many developing countries, severe restrictions on democratic institutions and norms (Malaysia, pre-1990 Zambia) or outright abrogation of democracy (Burma, Togo) have been justified by claims that multiparty democracy inevitably leads to ethnic polarisation and mobilisation, increasing the risk of violent ethnic conflict. Nor are such arguments the sole purview of despots seeking justification for their rule - Rabushka and Shepsle (1972) have developed a model of 'ethnic outbidding' and democratic instability in multiethnic countries. Yet the evidence suggests that where (de facto) one-party states emerge, these rarely fulfil their promise of inclusion. The one-party regime of Félix Houphouët-Boigny in Côte d'Ivoire has often been defended on such grounds, with the quick descent of the country into ethnic strife following democratisation only reinforcing these claims. However, there are many other cases where authoritarianism in the name of ethnic peace evidently became little more than an oppressive vehicle for ethnic dominance - the 1962 coup in Burma was largely legitimised on the failure of democratic politics to hold the union together, yet the Ne Win regime that took power and its successors have concentrated power in the hands of the ethnic Bamar (Callahan 2005; Smith 1999); in Togo, the long dictatorship of Étienne Eyadéma began with a 1967 coup 'depicted as forestalling an overt confrontation between north and south' 
(Brown 1983: 442), yet in the latter years of his long rule, Eyadéma stood accused of concentrating power not just in the hands of his own regional compatriots but in the hands of his Kabye tribe.

\subsection{Power-sharing in the executive}

While the electoral mechanisms discussed may reduce group exclusion from parliamentary assemblies, groups may still be excluded from political power unless there are arrangements to ensure power-sharing in the executive.

The group background of the executive itself - the head of the executive, particularly, but also the cabinet - is of crucial importance for decision-making. In many countries, the group that dominates the executive distributes resources in a way that favours its own members. For example, in Burundi in the 1990s, half of government investment went to Bujumbura and its vicinity, from where the elite Tutsi (who dominated the government) came (Gaffney 2000). Moreover, group exclusion has powerful symbolic importance which can lead to group mobilisation. In Côte d'lvoire, the exclusion of Alassaine Outtara, a northerner, from running in the presidential elections was a major factor in the alienation and mobilisation of northern groups against the Bédié regime (Langer 2005).

In a number of cases, many in post-conflict societies, formal mechanisms exist to 'share' the very top governmental positions among cultural groups. In Lebanon, the top three political offices are reserved for members of the three main ethno-religious groups - the president is constitutionally required to be a Maronite Christian, the prime minister Sunni Muslim, and the speaker Shi'a Muslim. In Cyprus, Greek Cypriots vote for the president; Turkish Cypriots for the vice-president. This type of power-sharing at the very top level can also be informally managed, as in Ghana, where a general expectation has evolved that the presidential and vice-presidential slates should include both a northerner and a southerner. Power-sharing can also take place over time. In BosniaHerzegovina, for instance, the chair of the three-member presidium rotates between the representatives of the Bosnian, Croat and Serb communities.

The policies discussed above are mostly formal mechanisms, but in many countries informal practices or customs have emerged with similar outcomes. In Côte d'lvoire, for instance, former long-running president Houphouët-Boigny applied an informal policy of ethnic balancing such that all major ethnic groups were represented within the most important political institutions and positions (Langer 2005).

Informal mechanisms may be less enduring and easier to subvert than formal, constitutionally enshrined ones, as illustrated in the case of Côte d'lvoire, where the informal 'compromis' of Houphouët-Boigny gave way under his successors. Informal mechanisms can be more extensive, more flexible and less open to the charge of entrenching identity politics than formal ones, and even apparently good formal mechanisms for power-sharing can be subverted - for example by giving only minor posts to some groups. Moreover, formal and informal mechanisms can complement each other. For instance, in Ghana, the constitution stipulates each region must be represented within the Council of State, which in turn advises the president on important public appointments and promotions. The formal, inclusive nature of this institution thus contributes towards promoting more balanced appointment policies. At the same time, this is backed up by many informal mechanisms. 


\subsection{The composition of the bureaucracy and the security services}

Power-sharing is an important issue not only at the political 'top', but also throughout the system, including, in particular, at high levels in the bureaucracy, the army and the police. Since the government is the largest employer in many countries, employment in the bureaucracy is very influential in terms of Hls in employment generally. In some countries, there are sharp HIs reflecting group dominance at the civil service level. For example, in Kenya, the Kikuyu, who form around $20 \%$ of the population, accounted for over $30 \%$ of the permanent secretaries in the civil service during the Kikuyu-dominated regime of Kenyatta, but dropped to just $11 \%$ in 1994 after a decade of Moi's rule. Meanwhile, the proportion from Moi's own ethnic group - the Kalenjin - increased from $5 \%$ in 1978 to $35 \%$ in 2001. A similar trend was evident in the composition of ambassadors and district commissioners (Kanyinga 2006). Some countries rely mainly on informal conventions to secure balanced representations. More explicit policies are needed, however, where there are gross inequalities. An unusual example is Nigeria's federal character principle, which requires balance in appointments in a comprehensive way (Mustapha forthcoming). In Ethiopia, too, the constitution requires ethnic proportionality at each level of government. Public appointment commissions for the bureaucracy can also play an important role if mandated to ensure a degree of ethnic balance in appointments and promotions. As noted above, this is the case in Ghana where the Council of State has balanced representation from the regions, and has the responsibility for making recommendations for high-level promotions and appointments.

\subsection{Diffusion of power}

Where power is concentrated in one body, it is easier for a single group to dominate and for others to be excluded than where power is more diffused. Diffusion can occur via division of powers at the national level through 'checks and balances', or via decentralisation of power. The US constitution provides a famous example of 'checks and balances' with power divided between executive, legislature and judiciary. Moreover, the two-house legislative body allows for regional representation (in the Senate) alongside more popular representation (in the House). Similar divisions of powers have quite frequently been adopted elsewhere, but they do not ensure comprehensive group participation if some groups are excluded from each of the branches of government, and/or one of the branches effectively dominates. Thus in the US case, the system has not been effective in ensuring full black participation in government. In many developing countries adopting a similar presidential system, the president effectively monopolises power, as in the case of Soharto's Indonesia.

Where groups are geographically concentrated, a federal constitution can empower different groups, by allowing them control over many areas of decision-making, the degree of empowerment clearly depending on the allocation of powers. Federal systems have been adopted in the multiethnic states of Belgium, Bosnia-Herzegovina, Ethiopia, India, Malaysia, Nigeria and Switzerland, among others, with the extent of devolved powers varying considerably among them - for example, Malaysia and Nigeria are both argued to be highly centralised, despite the federal constitution. The design of the federation is important, as shown by the Nigerian case, where the initial three-state constitution encouraged Biafran separatism. Following the 1967-1970 civil war, the Nigerian Federation was redesigned to encompass more states that straddled different ethnicities (Osaghae and Suberu 2005). 
Decentralisation can contribute to power-sharing in a similar way to federalism. But again much depends on which powers are given to the decentralised units and whether finance is also devolved. There are many cases of apparent decentralisation with little real devolution (Crook and Manor 1998). Even where there is real devolution, decentralisation can replace one set of power brokers with another. For example, decentralisation in Uganda has empowered majority groups in the local government area, but disempowered minority groups (Green 2006). Nonetheless, where groups are geographically concentrated, decentralisation may give some political power to previously underrepresented groups, though it can also lead to continued (or even greater) disempowerment for some (normally minority) groups within the decentralised areas, as is the case with both federalism and decentralisation in Nigeria. Econometric analysis has shown that decentralisation is associated with lower levels of communal and secessionist violence, but this can be partly offset by the growth of regional political parties (Brancati 2006).

In designing federal or decentralised institutions for the management of political HIs, a major consideration is how subnational boundaries should be drawn. Proponents of 'direct policies' (consociationalists) argue for subnational boundaries to be drawn, as far as possible, 'around' ethnic groups. Federalism, in this context, is seen as a means of allowing national minorities a degree of autonomy over their own affairs. In contrast, proponents of integrationism argue that boundaries should be drawn 'through' ethnic groups, in order to moderate ethnic political claims (Horowitz 1985). Critics of 'ethnofederalism' have pointed to the collapse of the post-Soviet federations Yugoslavia, Czechoslovakia, and the USSR itself - as evidence of its weakness (Snyder 2000), although McGarry and O'Leary (2006) have argued that all these collapses were preceded by moves away from the principle of ethnoregional autonomy. As with other policies discussed here, it is likely that the nature of subnational boundaries cannot be taken in isolation as a 'good' or 'bad' policy for HI management but rather must be contextualised with other policies and the broader political and demographic make-up of a country.

\subsection{Conclusions on policies towards political HIs}

Some general conclusions on appropriate policies towards political HIs can be drawn, but details must be country specific. It is important to accept the objective of powersharing across groups at many levels of government. While the easiest way to achieve this is with formal, direct mechanisms, there are many indirect mechanisms (formal and informal) which contribute to realising the objective. But with the latter, especially, it is important to monitor outcomes and be sure that they do indeed deliver a reduction in HIs. In sharply divided societies, formal direct mechanisms may be essential to persuade the various groups that power-sharing will indeed occur. This was the case historically in Belgium and Switzerland. Both are examples of quite explicit and formal power-sharing that has survived for centuries and produced peace, although, perhaps as a consequence, the various identities remain distinct in a way that is generally not the case in other European countries with more integrationist arrangements.

\section{Policies towards socio-economic Hls: affirmative action}

The term 'affirmative action' has been defined as 'positive steps taken to increase the representation of women and minorities in areas of employment, education, and business from which they have been historically excluded' (Fullinwider 2005). Essentially, this would cover any of the policies considered here for improving HIs, 
whether direct or indirect and this is how we use it here. While direct policies target the disadvantaged group(s) it is also usually possible to devise HI-reducing policies that take a more indirect approach to supplement, or make unnecessary, the more direct policies.

There is a very large range of policies that can constitute such affirmative action. This is because: (i) different approaches may lead to an improvement in Hls - e.g. legal approaches, expenditure led-approaches, quantitative targets and quotas; redistributionary approaches; (ii) there are many elements or categories in which improvement may be sought (e.g. within the social sector, access to health services at many levels, access to types of education and training, housing, water etc, and within the economy, access to employment at many levels, to many different types of asset and so on); and (iii) in the economic sphere, there are several levels of policy (macro, meso and micro).

We cannot be taxonomic in this review, but will rather touch on some important issues.

\subsection{Indirect approaches}

In general, indirect policies are often possible and are to be preferred if effective. These include progressive tax policies and general anti-poverty programmes which ipso facto benefit deprived groups relative to privileged ones. They also include regional tax and expenditure policies where groups are regionally concentrated. Moreover, where groups are concentrated within regions, expenditure allocations can be devised to favour deprived districts. Other indirect measures use the legal system, e.g. through legal recognition and enforcement of economic and social human rights and through strong and well-enforced anti-discrimination legislation. For example, in Peru, a Human Rights Ombudsman (Defensorio del Pueblo) has been instituted to help enforce the rights of indigenous peoples, while in Northern Ireland, effective legislation against employment discrimination was important. Resources for legal aid may be an important aspect of HIreducing policy.

Regional development policies are often relevant to addressing HIs because of the common regional concentration of groups and imbalances in regional development, often associated with colonial policy. Regional disparities in levels of socio-economic development typically have deep historical origins and are linked to geographical and climatic factors, exacerbated in many countries by a dependence upon primary commodities and natural resource exports, which are typically located in specific regions of the country. Where regional disparities overlap with, or correspond directly to, group identities, regional development policies may be an important and useful way of addressing horizontal inequalities indirectly, which may be particularly needed where relative under-development is correlated with 'adverse' geography. Yet, in many countries the regional distribution of infrastructure actually accentuates existing imbalances rather than correcting them. Evidence from Peru suggests that the influence [of geographic conditions] on expenditure levels and growth differentials [between Peruvian provinces] comes about through a spatially uneven provision of public infrastructure' (Escobal and Torero 2005: 106). In Mozambique, also, public investment has been concentrated in the relatively privileged south. Southern households have received considerably above-average infrastructural benefits of every kind since the conflict there ended, and the Centre has received least, apart from in school-building, where it did better than the North (Smith and Seltzer 2000). Data for aid distribution (which financed much of this infrastructure) also shows a strong bias towards the south. 
It is important to recognise, however, that even where regional inequalities are high, correcting such inequalities may not necessarily reduce all group inequalities. In Nepal, for instance, where regional inequality has been linked to the intensity of the country's Maoist insurgency (Gates and Murshed 2005), regional development policies would be likely to improve the conditions of the Janajāti ethnic groups, which are regionally concentrated, but would have less of an impact on the overall position of the Dalit (untouchable) castes, which are fairly evenly spread across the country (Gurung 2005). Moreover, even where groups are concentrated regionally (i.e. account for a large proportion of the population of a particular region), out-migration may mean that effective regional policy only reaches a proportion of the deprived group. For example, in Ghana over $30 \%$ of traditionally northern groups are in fact located in the south. It is important to note, however, that investment in public infrastructure and services, including education and health, in historically under-developed regions is often insufficient for an endogenous catch-up process to be set in motion. Additional investment into the promotion of self-sustaining economic activities and production is also necessary.

Another way of addressing horizontal inequalities indirectly where different groups are concentrated in different sectors of the economy involves targeted programmes that benefit the economic sectors in which the relatively deprived groups are concentrated, without targeting the group directly. Once again, the concentration of different ethnic groups in different sectors usually has deep historical roots, often associated with colonial 'ethnic division of labour' policies (e.g. Brown 1997).

Within the category of public expenditure allocation, it is important to recognise three distinct aspects of government expenditure: these are the construction of publicly financed facilities, such as infrastructure; the running of public facilities (for example, the group composition of health-sector workers); and the beneficiaries of the facilities (Stewart, Brown and Cobham 2006). Attempts to trace the (vertical) distributional impact of government expenditure have almost exclusively focussed on the third phase (Chu et al. 2004; van de Walle et al. 1995). Yet government investment accounts for a very large proportion of total investment in many developing countries, and the beneficiaries of contracts to carry out this expenditure are especially visible and their selection politically provocative. Government employment also typically constitutes a large proportion of total formal sector employment, and the distribution of these 'good' jobs is an important aspect of $\mathrm{HI}$ reduction in employment.

The fiscal system can also be designed to favour HI-reducing regional and sectoral policies through, for instance, tax incentives for investment in particular regions or sectors. Where there is decentralisation and group concentration at the district level, revenue-sharing formulae can be devised to improve the fiscal position of poorer districts, as was implemented in Indonesia's decentralisation programme. Similarly, specialised productive activities or sectoral concentration of groups makes it possible to use the tax system to differentiate among groups. In many contexts, particular groups are concentrated in trading, and taxes on wholesale and retail trade would alleviate HIs. The poorest people and groups are generally not in the formal sector so that direct taxes on the formal sector in general will help. In Niger, for example, most people in the informal sector are in a different ethnic group from those in the government and the formal sector generally (Barlow and Snyder 1993). 


\subsection{Direct approaches}

Partly because indirect policies take time and are not always effective, and often because of political pressure from poorer groups, direct approaches have quite often been adopted. Such programmes have been introduced both in the North (such as in the US, New Zealand, and Northern Ireland) and the South (such as in Fiji, India, Malaysia, South Africa, and Sri Lanka). These examples are instructive in pointing to the variety of policies possible. Some of the programmes have been introduced by disadvantaged majorities - for example in Fiji, Malaysia, Namibia, South Africa and Sri Lanka - and some by advantaged majorities for disadvantaged minorities - for example in Brazil, India, Northern Ireland and the US. The latter show that affirmative action can be introduced even where the political situation appears unfavourable.The following illustrative list shows the range of direct policies possible:

Assets

- Policies to improve the group ownership of land via redistribution of government owned-land; forcible eviction; purchases; and, restrictions on ownership (Malaysia, Zimbabwe, Fiji, and Namibia).

- Policies towards the terms of privatisation (Fiji).

- Policies towards financial assets: bank regulations; subsidisation; and restrictions (Malaysia and South Africa).

- Credit allocation (Fiji and Malaysia).

- Preferential training (Brazil and New Zealand).

- Quotas for education (Malaysia, Sri Lanka, and the US).

- Policies towards public sector infrastructure (South Africa).

- Policies towards housing (Northern Ireland).

- Incomes and employment

- Employment policies, including public sector quotas (Malaysia, Sri Lanka, India), and a requirement for balanced employment in the private sector (South Africa).

- Education

- Quotas for university entrants in Malaysia, Sri Lanka and Nigeria.

- Language policy used to strengthen the position of some groups and weaken that of others in school and university in Malaysia, Sri Lanka.

- Health

- Policies to improve health access and services in relatively deprived areas (Northern Ghana), or special efforts to improve access of the black population in the US.

Most of these policies involve targets, quotas and public expenditure directed at improving participation.

There is not space here to detail these numerous policies. many countries have adopted a partial approach to correcting Hls, with limited results (for example, Brazil). However, two country examples are instructive in showing how a comprehensive effort can improve socio-economic Hls.

- In Malaysia, the New Economic Policy was introduced in 1971, aiming to reduce inequalities between the Malays and the Chinese, following anti-Chinese riots in 1969. The aim was to help secure national unity. There was a two-prong approach: 'to reduce and eventually eradicate poverty'; and 'to accelerate the 
process of restructuring Malaysian society to correct economic imbalance so as to reduce and eventually eliminate the identification of race with economic function' (Second Malaysian Plan 1971-1975). In addition to a variety of antipoverty policies (rural development; social services), restructuring policies included expanding the bumiputera (an umbrella term for indigenous groups in Malaysia) share of capital ownership to $30 \%$; allocating $95 \%$ of new lands to Malays; instituting educational quotas in public institutions in line with population shares; and credit policies favouring Malays, with credit allocations and more favourable interest rates. The ratio of Bumiputera average incomes to Chinese moved from 0.42 to 0.57 between 1970 and 1999 (with the greatest improvement happening in the first ten years of the policy), the ratio of share ownership from 0.03 to 0.23 , and the bumiputera share of registered professionals went from $8 \%$ to $47 \%$ over the same period.

- In Northern Ireland, following centuries of strong discrimination and persistent HIs, a concerted effort was made from the late 1970s through housing policy, education policy and fair employment legislation, backed up by the EU and the British government reserving their contracts for firms that did not discriminate. From the late 1970s to the late 1990s, inequality in the share of the population in the high income category between Catholics and Protestants went from 0.55 to 0.77, the ratio of Catholics to Protestants in higher education moved from 0.39 to 0.81 , and inequality in the proportion of the population in houses with three or more rooms from 0.5 to 0.9 . By 2004 , inequalities in higher education and in access to basic health services had been eliminated.

\subsection{The need for economy-wide restructuring as well as fiscal and expenditure policies}

Experience shows that policies directed towards improving a group's human assets (notably education) are generally insufficient to improve economic Hls. Groups are handicapped by asymmetric social capital as well as inequality in economic assets and opportunities. Where improvements are made in human capital through education, groups' economic progress is nonetheless held back by these asymmetries. Although something can be done to improve economic opportunities via special credit programmes and directed infrastructural investment, this is likely to be insufficient without a broad restructuring of the economic activity across groups in the economy. This was recognised in Malaysia's New Economic Policy which explicitly aimed to change the colonial division of labour. Elsewhere economic policy is often 'blind' to these issues. This applies, notably, to structural adjustment policies the design of which does not take into account the group distributional implications of the policies, and can result in a substantial worsening of the position of deprived groups. This appears to have occurred in Ghana, Mozambique, Uganda, Nigeria, and South Africa where structural adjustment policies favouring tradable products raised incomes among the more privileged parts (and groups). In Ghana, despite flows of public and NGO investments to the north, less than $1 \%$ of private capital from outside Ghana has gone to 
the north in recent years. In South Africa, the economic model is claimed to have perpetuated economic apartheid. ${ }^{3}$

The implications of particular policy packages for Hls need to be explored and, where they widen HIs, policies either need to be modified or compensatory action taken. Privatisation is another element in adjustment packages which frequently has strong group distributional implications which are rarely taken into account. For example, in Mozambique the benefits of privatisation were monopolised by one (already privileged) group.

International aid can play an important role in $\mathrm{HI}$-reducing regional and sectoral development policies, although it also has the potential for a negative role, where aid distribution favours privileged regions or aid-imposed structural adjustment programmes contribute to increased HIs. Data for aid distribution in Mozambique (which financed much of the country's infrastructure) shows a strong bias towards the relatively privileged south. In 1997, average per capita aid disbursements for 1995-1997 were $\$ 18.5$ in the north; $\$ 71.87$ in the centre; and, $\$ 103.98$ in the south. Where domestic governments are already committed to implementing HI-reducing policies, aid in the form of general budgetary support may be the most appropriate mechanism for helping countries tackle their HIs. Where governments are unwilling or unable to implement HIreducing policies, however, project aid may be more appropriate through, for instance, basic service provision (e.g. health and education) in relatively deprived regions. International aid can also contribute to reducing Hls in countries where there are clear sectorally delimited HIs through such programmes as the EU's Export Earnings Stabilisation System (Stabex), which is a compensatory financial scheme to stabilise export earnings derived from primary agricultural commodities. Stabex as it is currently implemented, however, may in fact be contributing towards increasing HIs - for instance in Ghana, the vast majority of the $€ 141$ million Stabex transfers received since 1975 have gone to the cocoa and timber producers located in the southern regions. ${ }^{4}$ Suitably redesigned, however, such programmes could help to reduce Hls by providing price support for commodities cultivated in the more deprived areas. For instance, in the Ghanaian case - as also in Côte d'Ivoire and many other West African countries Stabex-type policies could be applied to support the cultivation of cotton and peanuts, which is largely located in the deprived northern regions.

International NGOs and local NGOs often play an important complementary role to the aid system in providing such basic services to deprived areas. For instance, in Ghana a wide range of international NGOs focus their activities in the relatively deprived northern regions, for example by setting up schools, developing water supply and providing other basic services.

3 'In general, neoliberal policies promoted by the World Bank and adopted by the ANC have helped black elites but done little for the black majority while largely preserving the status quo' (Schneider 2003: 45).

${ }^{4}$ EU-Ghana Development Co-operation Annual Report 2004; downloaded from http://delgha.ec.europa.eu/en/publications/EC\%20Ghana\%20Annual\%20Report\%202004.pdf

(last accessed 12 February 2007). 


\subsection{Monitoring outcomes}

Monitoring distributional outcomes is essential in order to assess the effectiveness of policies. This is especially relevant to indirect policies - where it is easy to claim that policies are effective in reducing HIs, yet data are often lacking. Information, even, on the regional distribution of government expenditure is often not available, as is the case in Ghana, for example.

\subsection{Integrationist policies}

Direct policies tend to enhance salience of identities while indirect policies are neutral in this respect. Socio-economic policies designed to increase integration include policies to encourage cross-group activities. In the realm of social policies, support for multicultural schools and social clubs and restrictions on exclusive schools/clubs may contribute; and in the economic sphere, policies that encourage cross-group economic engagement. Fiscal or other direct economic incentives for cross-ethnic (cross-group) economic activities is one option. An example here is the rules governing the floatation of companies on the stock exchange in Malaysia, which stipulate a minimum apportionment of share capital to bumiputera stockholders for new flotations. In this case there are no reverse limitations - i.e. there are no rules to prevent $100 \%$ bumiputera ownership, but these could easily be devised. This clearly applies only to the very 'top' end of the formal economy, however. Licensing requirements have extended this approach to lower levels of economic activity, but given that, in other contexts, deprived groups are often concentrated in the informal sector, it is more difficult to see how such incentives could be applied throughout the economic chain. In addition, such measures may not in fact work in increasing integration. The Malaysian system has been accused of creating a so-called 'Ali Baba' phenomenon in which a politically linked bumiputera investor (Ali, a common Malay name) provides the license and/or listing requirements for a Chinese entrepreneur (Baba, from a slang Malay term for the Chinese) but remains otherwise a silent partner (Heng and Sieh Lee 2000; Jesudason 1997). Recent research, however, has suggested that this approach has indeed been successful in generating 'genuine' cross-ethnic partnerships in the SME sector (Chin 2004). This is all the more important for political stability given that economic inter-dependence between groups is likely to reduce conflict potential.

\subsection{Standards and efficiency}

A common criticism of affirmative action policies is that they reduce standards (in the case of education) and efficiency (in the case of economic affirmative action). For instance, some claim educational quotas in the United States encourage mediocrity by giving places to less well-qualified black students in place of better qualified students. To the extent that the policies eliminate existing discrimination, however, efficiency should in fact be increased. But some of the policies appear to go further than this, actually creating 'positive' discrimination in favour of previously deprived groups. This is because long-term deprivation creates a deep bias against the groups, which simply removing current obstacles is insufficient to reverse. Hence positive discrimination can be viewed as offsetting the enduring impact of historic discrimination. It may actually therefore improve economy-wide efficiency by tapping the potential of the deprived groups and expanding the overall pool of human resources available.

There is, moreover, no significant evidence that such policies reduce efficiency, though careful evaluations are relatively rare. In theory, there are reasons for expecting the 
efficiency impacts to include both negative and positive elements. On the negative side, there is the interference in normal competitive processes which might prevent resources being allocated according to their most efficient use; but on the positive side is the offset (or reduction) in economic exclusion and relative deprivation which itself contributes to inefficient resource allocation, and may allow the greater exploitation of potential. The most systematic study of the efficiency impact has been with respect to US affirmative action towards blacks. Some studies show positive impact, while none show negative (Farley 1984; Keister 2000). In Malaysia, the high economic growth that accompanied the affirmative action policies also suggests that such policies are highly unlikely to have had any substantial negative efficiency impact, and may have had positive impact.

It is sometimes argued that, while affirmative action and other HI-reducing policies reduce inter-group inequality, they increase intra-group inequality. This is not inevitable a priori, but depends on whether the policies mostly extend the opportunities and services for lower-income classes (for example: unskilled employment; investment in poor regions; and primary education) within the deprived ethnic/cultural group(s), or mostly affect upper-income opportunities (professional and skilled employment; and, higher education). Systematic evidence on this is lacking. In the case of Malaysia, intragroup inequality fell during the decade when the policies were most effective (Shireen 1998). In contrast, in South Africa, it seems that intra-black inequality has risen since the policies were introduced (van den Berg and Louw 2004). The business 'empowerment' policies in South Africa, for example, seem mainly to enrich a black elite $^{5}$. In both cases, of course, many other influences were simultaneously affecting income distribution (such as the anti-poverty policies in Malaysia and the liberalisation policies in South Africa) so the changes cannot be attributed to the affirmative policies alone.

The possibility of some adverse impact of HI-reducing policies on efficiency and intragroup equity suggests that one should aim to design policies which tend by themselves (or in conjunction with other policies) to enhance efficiency and to improve income distribution. From an efficiency perspective, this might mean a greater emphasis on process reform and subsidies rather than quotas; and from an equity perspective, it would mean putting emphasis on employment and basic services, as well as infrastructure development in poor regions. It should also be noted that even if the policies potentially reduce efficiency and worsen intra-group income distribution, these effects would need to be weighed against their likely impact in reducing violence, which would itself have a positive effect on growth and efficiency and poverty reduction.

Another important consideration regarding socio-economic $\mathrm{HI}$ reduction relates to the demographic distribution of disadvantaged groups and the concomitant level of resources necessary to improve their position. Where the disadvantaged group is a small minority, the diversion of national resources required to improve their position will be relatively small when compared with the level of resources required to improve the

${ }^{5}$ Caroline Southey 'Black South Africans grow impatient over pace of change' Financial Times, Jan 05, 2007 
position of a disadvantaged majority. Taking this into account, the dramatic improvement in the relative position of the Malay/bumiputera majority in Malaysia under the NEP is all the more impressive.

\subsection{Conclusions on policies towards socio-economic HIs}

There is a large range of potential policies, both indirect and direct, for alleviating socioeconomic HIs, many of which have been adopted in parts of the world. Indirect policies are attractive in avoiding entrenchment of difference, but they tend to be slow and partial in their impact. Monitoring is important to ensure that such policies are effective. Economic policies that incorporate considerations of group equity are rare - and absent altogether in the case of macro and structural adjustment policies. Yet we find that only if there are economic as well as social policies to correct Hls is substantial improvement realised.

\section{Policies towards cultural status Hls}

Cultural status inequalities refer to 'differences in recognition and (de facto) hierarchical status of different groups' cultural norms, customs and practices' (Langer and Brown forthcoming). In addition to discontent brought about by (perceptions of) group-based political exclusion and socio-economic deprivation, groups also make claims regarding the status and recognition given to their cultural norms and practices - e.g. religious practices - within both public and private spheres. This is particularly important in relation to the cultural 'identity' of the state - whether it embodies cultural exclusivity or subordination of practices associated with certain cultural groups, or reflects a cultural inclusivity which places equal value and visibility on the cultural practices of all groups. Alternatively, the state can aspire to complete 'acultural' status, as in France.

This type of horizontal inequality differs in an important respect from political and socioeconomic Hls. While political and socio-economic $\mathrm{HI}$ management predominantly involves redistributive policies, rectifying cultural status inequalities is often a matter of recognition rather than redistribution. The three main areas of cultural status relate to religious practices and observances; language policy, particularly in education and administration; and ethno-cultural practices. The main objective of policy in this area is to achieve 'cultural status equality'.

\subsection{Religious practices and observances}

Freedom to pursue one's religion has long been recognised as a fundamental human right. In multireligious societies, differing levels of formal recognition or restrictions on the observance of religious practices are an important source of cultural status inequality. At one extreme, there are many historical examples of religious persecution. For instance, in the 1990s, Egypt forbade the rebuilding of Coptic Christian churches. In a less extreme example, states sometimes privilege one religion over others by adopting it as the 'national religion', which carries varying degrees of privilege. For example, in Malaysia, Islam is designated the official religion but the constitution guarantees freedom of religion for non-Muslims. Despite this, proselytisation of Muslims by non-Muslims is forbidden and, while not technically illegal, official recognition of apostasy for Muslims is in practice virtually impossible. Even secular states, however, where there is no officially favoured religion, frequently have a bias towards the majority religion. For example, in most secular Western European countries, Christianity retains a privileged public position through, for example, the designation of public holidays. 
Formally, the state's relationship with religion varies from a total lack of relationship (complete secularity) to complete integration (theocracy). Theocracies invest political legitimacy in a specific religious framework thus incorporating a strong hierarchy of religious recognition. Less extreme are explicitly non-secular states which nonetheless give official recognition to all major religions in the country; an example here is New Order Indonesia, where religion was taken as the basis of political legitimacy, but the five main religions of the country were all afforded equal status under the 'national ideology' of Pancasila (Ramage 1995). More generally, however, in non-secular states, religious minorities typically suffer various forms of exclusion.

Policies to bring about cultural equality across religions mostly have limited resource costs, although they might entail 'recognition' costs and are often highly sensitive. Examples of policies to bring about equality in religious recognition include ensuring equal opportunity to construct places of worship and burial grounds; recognition of religious festivals and, where appropriate, public holidays to commemorate them; inclusive laws regarding marriage and inheritance; and representation of all major religions at official state functions.

Ghana is an example of a country which has been relatively successful in promoting cultural status equality between religions and generating a religiously inclusive environment. Despite the fact that Muslims constitute only around $16 \%$ of the population, the Ghanaian state has taken positive steps - both symbolically and in concrete terms - towards establishing cultural status equality between Islam and Christianity. Thus, for instance, the government provides active institutional support for the Hajj and, in 1996, introduced a public holiday for Eid Al-Adha. Another important practice involves representatives of all major religions being present at all official state functions (Langer 2007).

In contrast, in many countries, informal practices can privilege certain religions over others, even when the state is officially neutral. The example in Côte d'Ivoire of Houphouët-Boigny's construction of the largest Catholic Basilica in the world in his home town of Yamoussoukro is a case in point. More generally, the fact that many political parties around the world have a particular religious affiliation and worldview may result in the alienation of other religious groups if these parties gain power. The association between political parties and religion can be either explicit, as with the Christian Democrats (CDU) in Germany, or associative, as with the Republican Party and the Christian Right in the United States.

One more intractable issue relating to religion is the designation of which days should constitute the 'weekend'. An interesting example of how this has been managed can be found in Malaysia, where the choice of weekend has been decentralised to the state level, so that some predominantly Muslim states take Friday and Saturday as their weekend, while others take Saturday and Sunday. In Nigeria, by contrast, some Muslim activists express discontent that Friday is still a normal working day.

\subsection{Language and language recognition}

The privileging of one or a few languages over others often signals the dominance of those for whom these languages are the mother tongue. Moreover, as the UNDP Human Development Report 2004 notes, 'Recognizing a language means more than just the use of that language. It symbolizes respect for the people who speak it, their culture and their full inclusion in society' (UNDP 2004: 9). At one extreme, governments 
may actively penalise the use of a minority language - a policy particularly associated with colonial governments in Africa, but also present today in a number of countries around the world (Crystal 2000: 84-5). A more common situation is the determination of a 'national' or 'official' language. This raises complex questions. Designating a single language as the national language is often seen as a means of promoting a cohesive and overarching national identity, but it can also generate resentment among minority language speakers who feel both symbolically excluded and also materially disadvantaged. UNESCO recommends a 'three language formula' promoting the use of an international language, a lingua franca, and mother tongue.

In practical terms, the ability to communicate between groups is vital for the effective functioning of a society. The UNDP gives a strong case for multilingual policies that is worth quoting in full:

In multilingual societies, plural language policies provide recognition to distinct linguistic groups. Plural language policies safeguard the use of two or more languages by saying, in essence, "Let us each retain our language in certain spheres, such as schools and universities, but let us also have a common language for joint activities, especially in civil life". Language conflicts can be managed by providing some spheres in which minority languages are used freely and by giving incentives to learn other languages, especially a national or official language (UNDP 2004: 60).

Language is an important element in the functioning of the state and the participation of citizens in substantive democratic practices. The official recognition afforded different languages is important here. Finding a formula for the degree of 'official' status afforded to different languages is often problematic, but some innovative policies have been developed. In Singapore, for instance, 'official' recognition is given to all four widely spoken languages: Malay, Mandarin Chinese, Tamil and English; government business is conducted in English, but Malay - a minority language - is designated the 'national' language, used for ceremonial occasions (Spolsky 2004). In contrast in Nigeria, only the three main indigenous languages of Hausa, Yoruba and Igbo are recognised as 'national languages', causing resentment among speakers of other minority languages. Clearly there is a trade-off between the cultural status benefits of recognition of minority languages and the economic costs involved in multiple official languages, such as translation costs and providing service access. This problem is linked to the degree of linguistic diversity; where only a few languages are present, the costs may not be prohibitive, but where many languages - in some cases hundreds - are spoken within one country, difficult decisions must be made. Ghana's policy towards language provides an interesting policy option, where English - an ethnically-neutral language - is the official language but successive governments have nonetheless actively promoted the study and teaching of (currently) 15 major Ghanaian languages within the context of, for instance, the Schools of Ghana Languages and Functional Literacy Programme (Bemile 2000). Indonesia adopted a similar strategy of selecting a minority ethnic language - Malay - rather than Javanese as the national language but promoted other languages through the formation of a state-sponsored linguistic institute which ultimately developed into a government ministry (Spolsky 2004). In addition to formal recognition policies, cultural status of languages can be affected through more informal mechanisms. Examples here include Belgium, where convention dictates that the prime minister employ both major languages - French and Dutch - in parliament and in dealing with the media, even to the extent of switching language mid-speech. 
The education sector is hugely important for language recognition. Alternatives include education in just the 'official' language, education in the 'mother tongue' plus the national language, or education in several of the languages spoken by the community. The chosen policy affects not only the cultural recognition of different groups, but also their economic prospects, since higher-level education and jobs generally require knowledge of the national language. It is apparent that promoting cultural status equality requires education in more than one language, though the specifics will vary across countries (see, for example, Watson 2007). While there are apparent opportunity costs of having to teach more than one language at school, the benefits of multilingual education outweigh this. Moreover, evidence suggests that where pupils are educated in their mother tongue and taught a national lingua franca (and possibly a third, international language), they perform much better at school - and therefore reduce overall costs compared to monolingual education. In Burkina Faso, for instance, $72 \%$ of pupils in bilingual schools obtained a primary education certificate, compared to only $14 \%$ in monolingual schools; annual recurrent costs per successful student were therefore about $25 \%$ lower in the bilingual schools (UNDP 2004).

\subsection{Policies towards ethno-cultural/religious practices}

The state's recognition of, and support, for the cultural practices of different groups is another important dimension of cultural status inequalities. Once again, large variations can be observed. At one extreme are explicitly prohibitive restrictions, sometimes referred to as 'cultural genocide' - such as the Chinese government's treatment of Tibetan culture. Even where states are broadly tolerant of cultural diversity, however, official practices may inadvertently privilige the dominant cultural group - such as national holidays, naming conventions (of buildings, streets, etc.) and promulgation of national 'heroes' and histories closely associated with the dominant cultural group. Attempts by the state to remain 'neutral' may sometimes be interpreted negatively by minority groups who associate 'neutrality' with de facto dominance of the majority culture. ${ }^{6}$ Lack of recognition of different cultural practices by the state can feed into broader informal practices within the society at large, including, for instance, employment discrimination against migratory minorities in many West European countries; frequent police searches of such groups; and assimilationist pressures, as in Guatemala, against indigenous students wearing indigenous dress. Stereotyping in the media also plays a role here.

An important factor in many countries concerns the treatment of customary law practices. On the one hand, lack of recognition of customary law practices can generate alienation towards the legal system as a whole among minority groups. Plural legal systems not only increase the access of these minorities to the legal system, but also their overall sense of being culturally valued. In Guatemala, for instance, the 1996 Accord on Indigenous Identity and Rights states that the lack of knowledge by the national legislative body of the customary norms that regulate indigeous community life, as well as the lack of access that the indigenous population has to the resurces of the national justice system, have caused negation of rights, discrimination and

\footnotetext{
${ }^{6}$ This was arguably the case when the French government introduced a ban on the wearing of any obvious religious symbols in schools and other public spaces, which was widely interpreted by Muslims as an attack on Islamic headscarves rather than a broader secular move.
} 
marginalization' (quoted in Buvollen 2002). In order to overcome this, the Guatemalan government and opposition agreed to implement a range of policies 'acknowledging the distinct cultures of indigenous peoples in Guatemala', such as free interpretation services for judicual proceedings into indigenous languages, cultural sensitivity programmes for judiciary members and recognition of indigenous communities' judicial norms (UNDP 2004: 59). Similarly, in Nigeria, the introduction of Islamic shari'a in many of the country's northern states has contributed to the sense of public recognition and acknowledgement among Muslims. ${ }^{7}$ At times, customary or religious legal systems may conflict with the underlying foundations of the civil legal code. Conflicts that emerge from such incompatibilities are often at the heart of the cultural status debate within multicultural and multireligious countries.

\subsection{Conclusions on policies towards cultural status inequalities}

Policies towards cultural status inequalities must take into account the country-specific histories, politics and demographies of cultural interaction. Having said this, the preceding discussion has highlighted a number of policy conclusions which appear to be common across a large range of countries.

The first conclusion is that there are important symbolic steps that states can take across all three main issues discussed here - religion, language, and ethnocultural practices - that would increase the visibility and recognition of different cultural groups without significant economic costs, although there may be political repercussions for the governments in question. State recognition and support for religious festivities, informal language-use practices and non-exclusive dress codes are all examples. Support for the study of different languages and the use of public holidays to recognise the cultural importance of different ethnic or religious identities are other relatively low-cost examples of HI-reducing policies in the cultural status dimension.

In other policy areas, however, there are much more tangible trade-offs and dilemmas. Language education and plural legal systems are examples here. We have suggested, however, that in many cases the trade-off may be exaggerated. Moreover, there are often possible options that allow a degree of compromise, as in the Singapore language example or Nigeria's selective implementation of, and the possibilities of civil appeal against, shari'a law.

In this section we have reviewed state policies. Yet the private sector, notably the media, plays an equally important role in conferring a sense of belonging or inferiority to particular groups, with respect to all three areas of policy discussed above. The state can set the broad framework for the operation of the media (e.g. outlawing 'race-hate' speech), and can subsidise media outlets presenting inclusive and/or alternative group visions. The (informal) cultural norms of a society - determining what is or is not acceptable - are of more importance in this realm however.

The final broad conclusion is that policies towards cultural status inequalities must themselves be designed and implemented under conditions of transparency, open dialogue, and inclusionary engagement between all cultures and the state. Without this,

\footnotetext{
${ }^{7}$ The law only applies to Muslims, however, and the court of appeal remains civil.
} 
policies of cultural neutrality, for instance, may be taken as indicating de facto dominance by the majority group.

\section{$7 \quad$ Managing change and policy obstacles}

In this section we discuss some general problems of initiating, implementing, and managing policy change in horizontally unequal societies. This raises important issues, first because the policies may meet vigorous opposition from the privileged groups who would lose, at least relatively, which may prevent the policies being initiated; or, in extreme cases, if poorly handled, HI-corrective policies can themselves contribute to the escalation of conflict, as seems to have been the case in Sri Lanka and Fiji. Secondly, as noted above, the policies can entrench ethnic difference. Hence it is important to introduce policies in a way that avoids these consequences, to the extent that this is possible. In this section we discuss three major issues relating to the implementation of policy: getting acceptance of policies; problems of resistance and perceptions; and how to avoid or limit the potential entrenchment of ethnicity.

\subsection{Initiating HI-management policies: getting support for the policies}

Much depends on the demographic composition of the population, and in particular whether the group which is deprived from a socio-economic perspective forms a majority or a minority of the population.

From a political perspective, the context in which corrective policies are easiest to introduce is one in which the socio-economically deprived group(s) is in a majority. This was the case in Malaysia, South Africa and Sri Lanka, so the initiation of HI-reducing policies was politically feasible. However, even this type of demography does not invariably lead to corrective action. For example, in Nigeria, northerners and Muslims form the deprived groups and are in a demographic majority. Yet there is little corrective action. A similar situation obtains in Bolivia. In such situations, it seems, the elite are satisfied with political power, and the associated economic benefits they acquire, and do not translate this into economic and social improvements for the broader group population. Such a situation may not be stable in the long run, however, as if ethnic leaders ignore their group's grievances too long, they might lose their support, which in turn might threaten their positions of power' (Langer 2005: 40). Of course, it there is no democracy, the minority privileged group may dominate the political system as well as the economic - as in Aparthied South Africa -and then changes are even less likely.

In other contexts, where the disadvantaged group constitutes a minority and the national government exclusively or mainly represents a dominant group, initiating $\mathrm{HI}$-corrective policies is more problematic. This is the case, for example, in many Latin American countries, where indigenous people form a small proportion of the total population. The same is true of the Roma people in Europe, and of many immigrant groups in Europe and elsewhere. Hence there is a need to persuade decision-makers of the importance of avoiding severe Hls for social and political stability. As noted above, this situation does not invariably form a decisive obstacle; some governments have introduced programmes to correct Hls where the deprived group is a minority - for example, in Ghana in relation to the north and in Brazil and the US in relation to the black population. Minority groups quite often mobilise to improve their position, and this can be effective in securing redistribution; such mobilisation was a factor leading to affirmative action in the US, for example. 
Correcting political HIs so that all groups participate in decision-making is likely to make the initiation of policies to correct socio-economic Hls more feasible politically. But this assumes a readiness to share power on the part of the majority group. Such a readiness may emerge from a sense of the importance of securing national unity and stability, which is an underlying reason for shared power in Ghana and Nigeria, for example, and in many 'post' conflict societies such as the Lebanon and Bosnia-Herzegovina. Powersharing is more likely to emerge if international norms move strongly in this direction.

This raises the issue of whether and how the international community should seek to use its influence to enforce some degree of $\mathrm{HI}$ correction. Aid donors can influence policy through discussions and norm-setting, without reverting to old-style 'conditionality'. Today such influence is mainly directed at achieving economic reforms of a fairly orthodox kind and securing commitment to poverty reduction and the Millennium Development Goals. Extending international influence to the need to monitor and correct HIs, however, would be likely to change the policy debate within developing countries. One important vehicle for the promulgation and discussion of policies is the Poverty Reduction Strategy Papers and the consultations that form part of the process. These currently cover around sixty low-income countries (World Bank 2005). While the consultative promise of the PRSP process was not met in the initial phase (Stewart and Wang 2006), a genuinely inclusionary PRSP that included representation of all groups in the country could lead to recognition of the importance of correcting $\mathrm{HIs}$ and the development of relevant policies. Indeed, this appears to have occurred with the recent PRSP in Nepal (Brown and Stewart 2006).

\subsection{Managing the implementation of HI policies: avoiding resistance}

Where governments choose to implement $\mathrm{HI}$-correction policies, there is a possibility that the policies generate social tensions, with resentment among losing groups. Where the policies are implemented on behalf of a disadvantaged majority, this may take the form of feelings of exclusion and 'second-rate citizenship' on the part of the privileged minority. In contrast, policies in favour of a disadvantaged minority may generate feelings of unfair treatment among sections of the majority - as is the attitude of many whites towards affirmative action in the US. As noted, the perceived loss of a position of dominance consequent on HI-corrective policies may be a source of conflict itself. In the Indonesian provinces of Maluku and Central Sulawesi, for instance, a major cause of conflict after the fall of Suharto was Christian resentment against pro-Muslim policies implemented in the last decade of his rule, which had seen their historical dominance severely undermined (Brown et al. 2005).

Ensuring that advantaged groups do not lose in absolute terms even as their relative advantage is eroded may be important as a means to encourage dominant groups to participate in HI-corrective policy processes and to secure the initiation and introduction of policy change. This may also help prevent the corrective policies leading to resistance by losing groups. As noted earlier, policies to correct HIs can be growth and efficiency promoting. The experience of Malaysia is instructive here. In its early years, 'the NEP was widely accepted across ethnic lines, especially after the traumatic May 1969 events [i.e. ethnic riots]' (Jomo 2004: 3). Moreover, the high economic growth of this period ensured that the Chinese gained in absolute terms, even as the bumiputera were improving at a faster rate. However, after the economic recession of the mid-1980s, which disproportionately affected the Chinese, increased resentment towards the NEP 
fed into a spiral of ethnic politics that brought the country to the brink of renewed rioting. Put simply, where the resources for $\mathrm{HI}$ correction mainly come from the benefits of strong economic growth, the policies are less likely to be politically contentious. In contrast, the Sri Lankan policies came at a time of high unemployment among the educated population, making job losses among the educated Tamil youth particularly provocative (ILO 1971).

Generally, for $\mathrm{HI}$ correction to be successful requires broad acceptance across all groups. One important issue here relates to varying perceptions of the causes of horizontal inequality and, hence, the 'fairness' of remedial policies. This is illustrated by differing attitudes towards affirmative action in the US. Based on the 1996 General Social Survey, Smith and Seltzer (2000: 34) note that 'there is a tendency for blacks to blame racism for their lower status in America, whereas whites tend to blame blacks themselves.' For instance, while $64 \%$ of the blacks in this survey saw 'past discrimination' as a major cause of black inequality, only $35 \%$ of the whites had a similar view. Dissemination of objective research on the nature and causes of HIs may make a contribution to correcting perceptions and securing national support for policies to correct such inequalities.

Broad transparency in policy implementation is also important in providing legitimacy for $\mathrm{HI}$ correction. In Malaysia, lack of transparency is behind current criticisms of the NEP, which is sometimes seen as no more than a rhetorical policy to justify clientalism which favours a select few (Gomez 1997).

\subsection{Managing the implementation of HI policies: the entrenchment of ethnicity}

It is often argued that affirmative action 'entrenches' ethnic difference and encourages segregation rather than integration (e.g. Jomo 2004). Whether this is so is largely dependent on the nature of the policies, as we have argued above. For example, political provisions for separate and compulsory electoral rolls and reserved seats and jobs might entrench difference whereas redesign of electoral districts to promote diversity of representation, or PR, or transferable votes are unlikely to do so. Similarly, policies which provide economic entitlements according to ethnicity may entrench difference, but regional expenditure policies may not. Consequently, wherever possible an integrationist approach is to be preferred. But positive discrimination of an overt kind may sometimes be the only way of achieving rapid progress. In such situations, a timelimit on the policies is desirable.

Affirmative action policies have also been criticised for encouraging new forms of prejudice and cultural stereotyping. For example, in Malaysia the policies have contributed to perceptions among non-Malays that successful Malays are undeserving cronies who would not gain such status in their own right. But people's perceptions of other groups are also influenced by their relative position and the nature of their interaction with them. Hierarchical ranking of cultural groups can generate social prejudices and stereotypes, but as the previously underprivileged move higher up the social scale, then meeting as equals will increase and inter-group respect likewise. Indeed, research into how far group interaction improves inter-group relations has indicated that it improves it when the groups meet as relatively equal, but not when they meet in an unequal relationship (Allport 1954; Hewstone and Brown 1986). Thus, if 
effective, HI-reducing policies may reduce ethnic stereotyping and this could be at least as important as any new forms of stereotyping.

\section{Conclusions}

Sharp HIs can have many adverse consequences, the most serious being mobilisation for violent conflict. It is therefore important to introduce policies to correct them. Action is needed to correct political inequalities and those in cultural status, as well as socioeconomic Hls. The appropriate policies depend on the particular context and a first step in designing policies is a full analysis of that context and the dynamics of Hls.

There are many policies that have an impact on group distribution, and that might be adopted to moderate HIs, as reviewed in this paper. We differentiate two approaches: a direct approach and an indirect one. The first involves giving entitlements to people, whether political or economic, because of their group affiliation, while the second involves correcting Hls by more general policies that have the effect of improving HIs but without specifying group affiliation. In general, the indirect policies have the advantage that they are less likely to enhance the salience of ethnicity, and may indeed contribute to integration, while the direct policies tend to reduce integration.

Some HI-correcting policies have been introduced extensively across multiethnic countries, but mostly in a piecemeal way. There is no evidence, however, that such policies have reduced efficiency or growth. It seems that policies towards political HIs are more common than policies towards socio-economic ones. Perhaps surprisingly, policies that tackle both political and socio-economic inequalities are relatively rare. Where policies are put into effect in a piecemeal way they do not seem to have a big impact. But where policies are put into effect systematically, across social and economic dimensions they can be effective in reducing HIs and in sustaining peace. Northern Ireland and Malaysia are examples briefly discussed in the paper.

However, despite their importance, in general, policies to correct economic and political HIs do not seem to feature in a significant way in the recommendations by donors for development or post-conflict policy change. The usual policy package recommended on the socio-economic side is to combine orthodox economic reform with poverty reduction, with no reference to group inequalities. On the political side, the overriding recommendation is for multi-party democracy and respect for human rights, again without any explicit policies towards political HIs. While governments in heterogeneous countries sometimes introduce some such policies, they rarely form part of the international policy agenda.

Policies towards HIs, however, are related to three different strategies which are currently widely advocated. First, HI reduction would generally contribute to poverty reduction, although poverty reduction strategies alone are not sufficient to bring about $\mathrm{HI}$ reduction in a systematic way. This is because poverty reduction strategies do not deal with political representation and participation, nor generally with discrimination. Indeed, poverty reduction can be achieved nationally while HIs increase, as has occurred in Ghana. An HI approach, however, would help reach some otherwise intractable areas of policy for poverty reduction - notably where discrimination is at the root of the prevalent poverty, as for example in some Latin American countries. Secondly, policies to eliminate social exclusion are closely related to policies towards Hls, and they also 
incorporate a multidimensional approach. However, there is more precision about Hls than social exclusion - HIs are easier to monitor, while some important HIs occur without being so extreme as to merit the term 'social exclusion'. Nonetheless, effective policies towards social exclusion would contribute greatly to reducing $\mathrm{HIs}^{8}$. Thirdly, the Human Rights approach to development, now widely accepted, also has much to contribute to the reduction of Hls. In particular, on the political side, enforcing the International Covenant of Civil and Political Rights would assist in reducing political Hls, but might not be sufficient on its own; on the social, economic and cultural side, promoting the realisation of the International Covenant of Economic, Social and Cultural Rights would contribute greatly to reducing socio-economic and cultural status HIs, while the rights concerned with eliminating discrimination would contribute to reducing HIs of all kinds.

Finally, it must be emphasised that policies to address Hls are, of course, not the only policies needed for development, generally or in a specifically post-conflict environment. Policies to promote economic growth and reduce poverty and vertical income distribution are also important aspects of the development agenda, while in a post-conflict setting, the resumption of economic growth is needed, and the reconstruction of economic and social infrastructure, as well as policies to promote successful and peaceful demobilisation. Particular emphasis is needed on promoting employment for unskilled labour in all poor countries, since lack of employment among young men is a common feature of poor countries, as well as constituting an important factor raising the risk of conflict.

The existence of other policy objectives means there may be trade-offs. How severe these trade-offs are depends on whether meeting one objective really is at the expense of another. It is possible to exaggerate this. Thus, there is no evidence that improving HIs needs to reduce growth, since it involves extending education and resources to people whose potential has previously been underused. Moreover, if Hls are so severe that conflict threatens, avoiding this is necessary to promote growth and poverty reduction in the long run. But, at least in the short run, there can be trade-offs; in such a situation, an elected government must consider how much they value an inclusive political and economic system compared with their other objectives.

We have noted that in many contexts there is political resistance to policies to correct HIs. While these policies may encounter difficulties, the more that consideration of group inequality becomes part of the norms of policy-making in peace time as well as in post-conflict situations, the more likely that action towards Hls will become part of routine policy-making.

${ }^{8}$ See Stewart (2004) for a more detailed discussion of the relationship between the $\mathrm{HI}$ and Social Exclusion approaches. 


\section{References}

Alatas, S. H. 1977 The Myth of the Lazy Native: A study of the image of the Malays, Filipinos and Javanese from the 16th to the 20th century and its function in the ideology of colonial capitalism, London: Frank Cass.

Barlow, R. and Snyder, W. 1993 'Taxation in Niger: Problems and proposals', World Development 21(7): 1179-1189.

Bemile, S. K. 2000 'Promotion of Ghanaian languages and its impact on national unity: The Dagare language case', in C. Lentz and P. Nugent (eds) Ethnicity in Ghana: The limits of intervention, Basingstoke: Macmillan.

Brancati, D. 2006 'Decentralization: Fueling the fire or dampening the flames of ethnic conflict and secessionism', International Organization 60: 651-685.

Brown, D. 1983 'Sieges and scapegoats: The politics of pluralism in Ghana and Togo', The Journal of Modern African Studies 21(3): 431-460.

Brown, G. 2005 'Playing the (non)ethnic card: The electoral system and ethnic voting patterns in Malaysia', Ethnopolitics 4(4): forthcoming.

Brown, G. and Stewart, F. 2006 'The implications of horizontal inequalities for aid' CRISE Working Paper No. 35, Oxford: Centre for Research on Inequality, Human Security and Ethnicity, University of Oxford.

Brown, G. K., Tajima, Y. and Hadi, S. 2005 Overcoming Violent Conflict: Peace and Development Analysis in Central Sulawesi, Vol. 3, Jakarta: Conflict Prevention and Recovery Unit, United Nations Development Programme (CPRU-UNDP), Lembaga IImu Pengetahuan Indonesia (LIPI), Badan Pusat Perencangan Nasional (BAPPENAS). Brown, I. 1997 Economic Change in South-East Asia, c.1830 - 1980, Kuala Lumpur: Oxford University Press.

Buvollen, H. P. 2002 Cultural and legal barriers to justice in Guatemala, Oslo: UNDP Access to Justice Workshop, 1 March 2002, downloaded from http://www.undp.org/governance/cd/documents/34.pdf (last accessed 12 February 2007).

Callahan, M. 2005 Making Enemies: War and state building in Burma, Ithaca, NY: Cornell University Press.

Chin, Y. W. 2004 'Ethnicity and the transformation of the Ali-Baba partnership in the Chinese business culture in Malaysia', in B. K. Cheah (ed) The Challenge of Ethnicity: Building a nation in Malaysia, Singapore: Marshall Cavendish International.

Chu, K.-Y., Davoodi, H. R. and Gupta, S. 2004 'Income distribution and tax, and government social spending policies in developing countries', in G. A. Cornia (ed) Inequality, Growth and Poverty in an Era of Liberalization and Globalization, Oxford: Oxford University Press.

Crook, R. C. and Manor, J. 1998 Democracy and Decentralisation in South Asia and West Africa: Participation, accountability and performance, Cambridge: Cambridge University Press.

Crystal, D. 2000 Language Death, Cambridge: Cambridge University Press.

Escobal, J. and Torero, M. 2005 'Adverse geography and differences in welfare in Peru', in R. Kanbur and A. J. Venables (eds) Spatial Inequality and Development, Oxford: Oxford University Press.

Farley, R. 1984 Blacks and Whites: Narrowing the gap? Cambridge, MA: Harvard University Press.

Foster, J.E., Lopez-Calva L.F. and Miguel Szekely. 2003 Measuring the Distribution of Human Development: Methodology and an Application to Mexico, Estudios Sobre Desarrollo Humano, PNUD Mexico, n. 2003-4 
Foster, J.E. and Miguel Szekely. 2006 Is Economic Growth Good for the Poor? Tracking Low Income Using General Means, mimeo, Vanderbilt University.

Fullinwider, R. 2005 'Affirmative Action', in E. N. Zalta (ed) The Stanford Encyclopedia of Philosophy, Spring 2005 Edition, Available online at:

http://plato.stanford.edu/entries/affirmative-action/ (last accessed 8 February 2007).

Gates, S. and Murshed, M. S. 2005 'Spatial-horizontal inequality and the Maoist insurgency in Nepal', Review of Development Economics 9(1).

Green, E. 2006 'Decentralization, district creation and conflict in Uganda' Paper presented at the CRISE Conference on Federalism, Decentralization and Conflict, 5-7 October 2006, Oxford: Centre for Research on Inequality, Human Security and Ethnicity, University of Oxford

Gomez, E. T. 1997 Political Business: Corporate involvement of Malaysian political parties, Townsville: Centre for South-East Asian Studies, James Cook University of North Queensland (1994) and Edmund Terence Gomez and Jomo Kwame Sundaram, Malaysia's Political Economy: Politics, patronage and profit, Cambridge: Cambridge University Press

Gurung, H. 2005 'Nepal Regional Strategy for Development' ADB Nepal Resident Mission Working Paper No. 3, Kathmandu: Asian Development Bank.

Hadiz, V. R. 2004 'Decentralisation and democracy in Indonesia: A critique of neoinstitutionalism perspectives', Development and Change 35(4): 697-718.

Heng, P. K. and Sieh Lee, M. L. 2000 'The Chinese business community in Peninsular Malaysia, 1957-1999', in K. H. Lee and C.-B. Tan (eds) The Chinese in Malaysia, Shah Alam: Oxford University Press.

Horowitz, D. L. 1985 Ethnic Groups in Conflict, Berkeley: University of California Press. - 1989 'Incentives and behaviour in the ethnic politics of Sri Lanka and Malaysia', Third World Quarterly, 10:4 (1989), pp. 18-35

International Labour Organisation (ILO). 1971Matching Employment Opportunities and Expectations. A Programme of Action for Ceylon. Geneva. ILO.

Jesudason, J. V. 1997 'Chinese business and ethnic equilibrium in Malaysia', Development and Change 28(1): 119-141.

Jomo, K. S. 2004 'The New Economic Policy and interethnic relations in Malaysia', United Nations Research Institute for Social Development; Identities, Conflict and Cohesion Programme Paper 7.

Keister, L. A. 2000 Wealth in America: Trends in wealth inequality, Cambridge: Cambridge University Press.

Langer, A. 2005 'Horizontal inequalities and violent group mobilisation in Côte d'Ivoire', Oxford Development Studies 33(1): 25-45.

- 2007 'The peaceful management of horizontal inequalities in Ghana' CRISE Working Paper No. 25, Oxford: Centre for Research on Inequality, Human Security and Ethnicity, University of Oxford.

Langer, A. and Brown, G. forthcoming 'Cultural Status Inequalities and (Violent) Group Mobilisation', CRISE Working Paper No. 41, Oxford: Centre for Research on Inequality, Human Security and Ethnicity, University of Oxford.

Lijphart, A. 1977 Democracy in Plural Societies: A comparative exploration, New Haven: Yale University Press.

- 1986 'Proportionality by non-PR methods: Ethnic representation in Belgium, Cyprus, Lebanon, New Zealand, West Germany, and Zimbabwe', in A. Lijphart and B. Grofman (eds) Electoral Laws and Their Political Consequences, New York: Agathon Press. - 2004 'Constitutional design for divided societies', Journal of Democracy 15(2): 96109. 
McGarry, J. and O'Leary, B. 2006 'Must pluri-national federations fail?' Paper presented at the CRISE Conference on Federalism, Decentralization, and Conflict, Oxford: Centre for Research on Inequality, Human Security and Ethnicity, University of Oxford: 6-8 October 2006.

Mustapha, A. forthcoming 'Institutionalizing ethnic representation. How effective is the Federal Character Commission in Nigeria?' CRISE Working Paper 43, Oxford: Centre for Research on Inequality, Human Security and Ethnicity, University of Oxford

Osaghae, E. E. and Suberu, R. 2005 'A history of identities, violence and stability in Nigeria' CRISE Working Paper No. 6, Oxford: Centre for Research on Inequality, Human Security and Ethnicity (CRISE), University of Oxford.

Rabushka, A. and Shepsle, K. A. 1972 Politics in Plural Societies: A theory of democratic instability, Columbus: Merrill.

Ramage, D. E. 1995 Politics in Indonesia: Democracy, Islam and the ideology of tolerance, London: Routledge.

Reynolds, A. 2006 'Election systems and the protection and participation of minorities', London: Minority Rights International.

Scheider, G. 2003 'Neoliberalism and economic justice in South Africa: revisiting the debate on economic apartheid', Review of Social Economy LXI, 1 23-50.

Shireen, M. H. 1998 Income Inequality and Poverty in Malaysia, Oxford: Rowman and Littlefield.

Smith, M. 1999 Burma: Insurgency and the politics of ethnicity, London: Zed Books.

Snyder, J. 2000 From Voting to Violence, New York: W.W. Norton.

Spolsky, B. 2004 Language Policy, Cambridge: Cambridge University Press.

Stewart, F. 2004. 'The relationship between Horizontal Inequalities, Vertical Inequality and Social Exclusion'. CRISE Newsletter No. 1, Winter 2004. Oxford: Centre for Research on Inequality, Human Security and Ethnicity, University of Oxford Stewart, F., Brown, G. and Mancini, L. 2005 'Why horizontal inequality? Issues of application and measurement' CRISE Working Paper No. 19, Oxford: Centre for Research on Inequality, Human Security and Ethnicity, University of Oxford.

Stewart, F. and O'Sullivan, M. 1999 'Democracy, conflict and development: Three cases', in G. Ranis, S.-C. Hu and Y.-P. Chu (eds) The Political Economy of Comparative Development into the 21st Century: Essays in memory of John C.H. Fei, Vol. 1, Cheltenham: Edward Elgar.

Stewart, F. and Wang, M. 2006 'Do PRSPs empower poor countries and disempower the World Bank, or is it the other way round?' in G. Ranis, J. R. Vreeland and S. Kosack (eds) Globalization and the Nation State, London: Routledge.

UNDP 2004 Human Development Report 2004, New York: United Nations Development Programme.

van de Walle, D., Nead, K. and World Bank 1995 Public Spending and the Poor: Theory and evidence, Baltimore: Johns Hopkins University.

van den Berg, S. and Louw, M. 2004 'Changing patterns of South African income distribution: Towards time series estimates of distribution and poverty', South African Journal of Economics 72(3).

Varshney, A. 2002 Ethnic Conflict and Civic Life: Hindus and Muslims in India, New Haven: Yale University Press. 